\title{
"Gringsing" Jalinan Estetika-Mitos Ritus Perang Pandan
}

\author{
Citra Aryandari ${ }^{1}$ \\ Jurusan Etnomusikologi, Fakultas Seni Pertunjukan, \\ Institut Seni Indonesia Yogyakarta
}

\begin{abstract}
Estetic and Mytos of Pandanus War. Gringsing The name of Gringsing is explained in popular etymology as meaning free from sickness, which is in itself enough to indicate that the cloths are honoured by the people because of their magic influence. The origin of the gringsing cloths is traced back to Dewa Indra, who created shadows in the sky so that they could be copied as pattern in the cloths. As was pointed out, the weaving of the gringsing, a sacred activity for the women. The weaving women have to take a number of adat regulations into account. Throughout Bali weavers are srict in following the adat. In he village of Tenganan Pegringsingan itself the use of certain gringsings is prescribed for specified ceremonies. Tenganan Pegringsingan community perform religious rites everyday to maintain the balance of the village. Tenganan Pegringsingan has unique culture, and all refer to the concept of balance. The most famous ritual activities in Tenganan Pegringsingan is Pandanus War. In Pandanus War, gringsing always used by Truna and Daha. They believe in using gringsing, they will be spared from disease. Gringsing present in Tenganan Pegringsingan bringing myths and aesthetics. Gringsing is a picture of a community cultural order Tenganan Pegringsingan. All have been recorded in awig-awig Tenganan Pegringsingan.
\end{abstract}

Keywords: Gringsing, estetika, mitos

\section{Pendahuluan}

Mitos yang berkembang di Tenganan sangat kuat. Pemujaan terhadap Dewa Indra menyimpan kisah unik setidaknya di lingkungan masyarakat Tenganan. Merujuk mitologinya, kawasan Tenganan dan sekitarnya pada waktu silam diyakini berada di bawah kekuasaan seorang raja yang lalim dan otoriter. Raja kejam dan lalim bernama Maya Denawa yang menurut kisahnya menjadikan dirinya sebagai Tuhan dan melarang orang Bali melakukan ritual keagamaan. Menyaksikan perilaku Maya Denawa yang semakin kejam dan bengis, para dewa di surga pun murka. Mereka lalu mengutus Dewa Indra dengan tugas khusus memimpin pertempuran melawan Maya Denawa. Melalui pertempuran sengit, Maya Denawa dapat dilumpuhkan dan Dewa Indra lalu tampil sebagai penggantinya.

Hingga saat ini desa Tenganan Pegringsingan tetap menjaga adatnya dan membedakan dirinya dengan orang-orang Bali lain yang beragama Hindu-Bali sebagai bagian dari masyarakat Majapahit. Orang-orang Tenganan tetap meyakini dirinya sebagai warga yang asli keturunan dari India. Mereka menyadari bahwa setiap waktu ada kekuasaan-kekuasaan otoriter yang mesti dilawan.
Lewat mitos di atas masyarakat diingatkan untuk melakukan ritual-ritual, memberikan penghormatan kepada kekuatan-kekuatan yang menciptakan kedamaian.

Di tengah arus perkembangan dunia yang mengglobal, tradisi perang pandan secara tidak langsung selalu mereproduksi mitos Dewa Indra. Selain mejadi bagian upacara adat warga Tenganan, tradisi ini juga menjadi bagian dari upacara pariwisata dunia. Mekipun pada satu sisi masyarakat Tenganan sangat kuat dalam menjaga adat, teguh menjaga budaya, akan tetapi juga menjadi bagian dari arus perubahan dunia. Inilah hal yang menarik dari profil masyarakat ini. Mitos Dewa Indra selalu dihidupkan dalam tradisi perang pandan untuk memaknai pertarungan, menjaga kekuatan untuk tetap teguh pada tataaturan yang telah digariskan oleh leluhur.

Perang pandan merupakan tradisi yang dilaksanakan setiap tahun. Perang pandan yang lazimnya berlangsung selama dua hari dilakukan oleh laki-laki Tenganan dengan cara berhadapan saling berpasangan untuk bertarung. Mulai dari anak-anak hingga dewasa terlibat dalam kegiatan ini. Mereka menggunakan tameng dari rotan serta senjata dari daun pandan berduri yang 

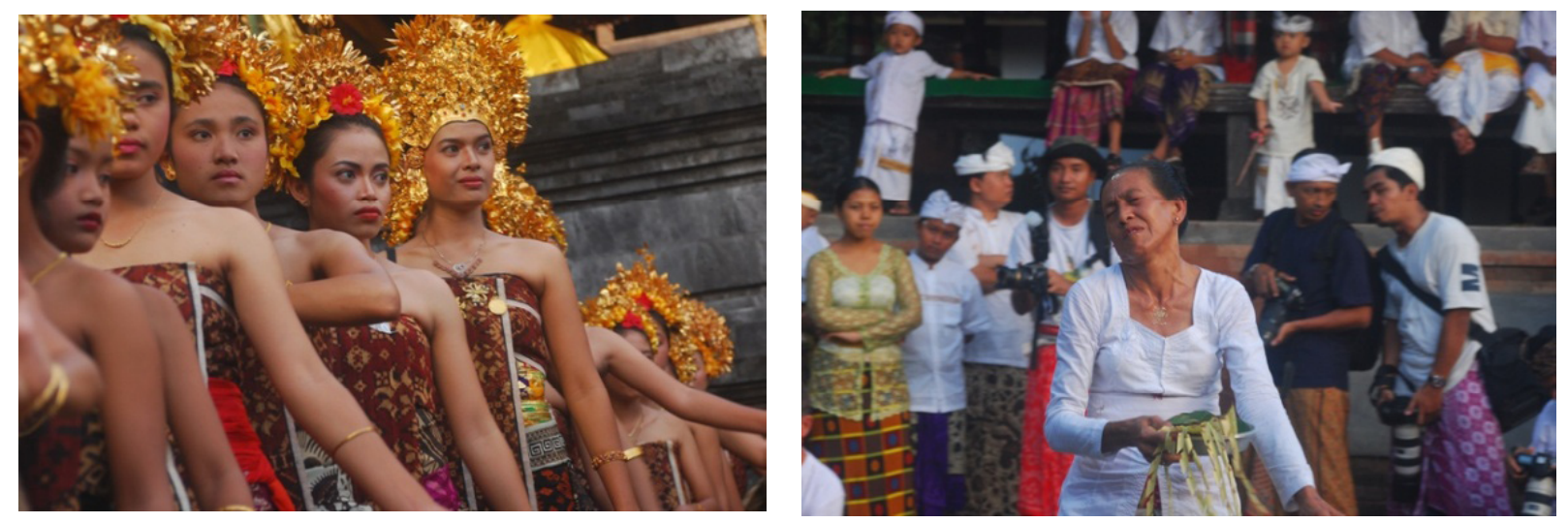

Para gadis yang sedang menarikan Rejang dengan kain gringsing (kiri) melihat ke arah perempuan yang "kerawuhan" (kanan) di jaba-tengah Pura Desa Tenganan. Acara ini berlangsung setelah berakhirnya perang pandan (Foto: Citra, 2008).

diambil dari pegunungan. Dalam pertandingan satu babak itu dipertontonkan aksi saling pukul dan menggosokkan daun pandan yang berduri ke tubuh lawan. Pertarungan berakhir bila salah satu telah jatuh atau memang dihentikan oleh juru pisah. Setelah itu dilanjutkan untuk pasangan berikutnya dan seterusnya sampai semua peserta mendapatkan giliran. Sorak-sorai terdengar saat di arena ada yang tergores atau terjatuh. Tak jarang pula ada tawa panjang karena ada yang bertarung dengan sikap-sikap yang lucu. Perang pandan menyuguhkan pemandangan kontras. Perang pandan di Tenganan tak ada duanya di Bali atau daerah lainnya. Atraksi itu merupakan salah satu kekhasan kampung ini sehingga harus terus dipertahankan dan dilestarikan. Perang pandan bukanlah atraksi yang akan berakhir dengan posisi kalah atau menang bagi para pelaganya. Atraksi ini adalah bagian dari ritual pemujaan masyarakat Tenganan kepada Dewa Indra. Sang dewa perang itu dihormati dengan darah sehingga atraksi perang pandan dilakukan tanpa rasa dendam. Mereka justru melakukannya dengan senyum ceria, meski harus saling melukai dengan duri pandan.

Tak hanya laki-laki yang berperan dalam perang pandan, perempuan memiliki andil dalam prosesi ritual tersebut. Perempuan muda dihadirkan dalam arena perang untuk menyemangati para jejaka yang sedang bertarung menggunakan senjata daun pandan. Peran perempuan secara implisit nampak sebagai motivator, khususnya bagi para ksatria yang akan terjun ke medan laga. Kemudian pada akhir kegiatan perang pandan, perempuan Tenganan memiliki kesempatan untuk menampilkan tarian Rejang. Tari Rejang memiliki gerak tari yang sederhana dan lemah gemulai. Pertunjukan ini ditarikan oleh remaja putri hingga anak-anak. Rejang dilakukan di jabatengah pura dan dilakukan secara berkelompok. Para gadis penari menggunakan kain gringsing.

Kain gringsing diketahui sebagai ciri khas Desa Tenganan yang berbentuk kain tenun ikat. Tidak diketahui secara pasti kapan kain gringsing mulai muncul di Tenganan Pegringsingan. Tiada diketahui pula siapa yang pertama kali memperkenalkan kerajinan menenun kain ini di Tenganan Pegringsingan. Kain gringsing mengandung makna sebagai semacam penolak bala. Ini jika dilihat dari kata gringsing yang berasal dari kata gring yang artinya 'sakit' dan sing yang artinya 'tidak'. Dengan begitu gringsing berarti 'terhindar dari sakit'. Kain gringsing ini sendiri bisa dikatakan unik, otentik dan kini amat langka. Bila dilihat dari proses pewarnaan, mengikat benang hingga menenun, untuk sehelai kain bisa menghabiskan waktu minimal satu tahun dan bahkan bisa 10 tahun. Waktu terlama dihabiskan untuk proses pewarnaan yang pemeramannya bisa bertahuntahun demi mendapat warna yang "matang". Ini pun bisa berisiko dalam pewarnaan. Warna yang dihasilkan bisa tidak sesuai dengan yang diinginkan.

Pewarnaan selalu menggunakan bahan alam. Warna dasar kuning didapat dari minyak kemiri. Kemudian bagian-bagian benang katun diikat kuat-kuat, dari sinilah nama ikat dikenal di seluruh dunia. Untuk mendapatkan warna biru indigo didapat dari cairan daun Indigo tinctoria. Selanjutnya pemberian warna merah berasal 

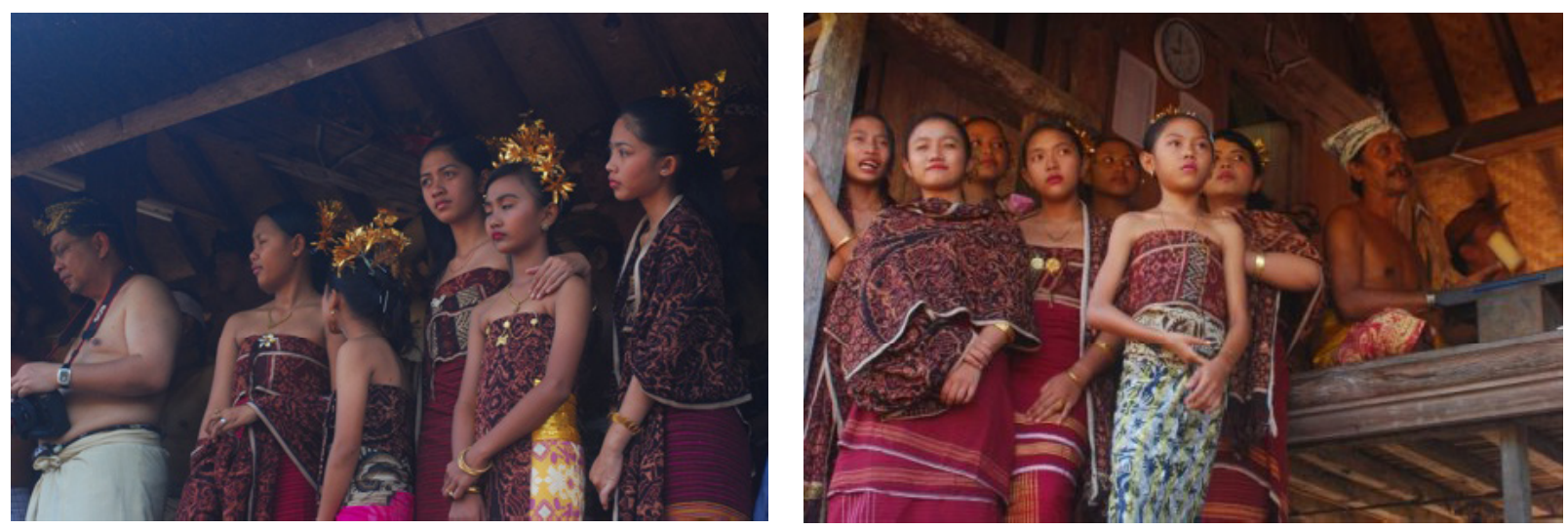

Gadis Tenganan dengan kain gringsing berdiri di Bale Agung menyaksikan para Satria Bali Aga bertarung (Foto: Citra, 2008).

dari kulit akar pohon sunti (Morinda citrifolia). Pekerjaan terumit adalah mengikat dan ini hanya dilakukan oleh seseorang dengan keahlian khusus di wilayah itu. Tidak sembarang orang bisa mengikat. Demikian juga dengan memberikan warna. Semua bagian dilakukan oleh orang-orang yang khusus dengan bagiannya.

Menenun adalah kerja perempuan. Hampir semua perempuan di Tenganan terlibat di dalamnya karena kain merupakan inti kehidupan Tenganan. Masyarakat Bali Aga dan orang di luar Tenganan percaya bahwa gringsing memiliki kekuatan magis yang melindungi mereka dari sakit dan kekuatan jahat. Selain itu semua ritual adat melibatkan kain. Tenganan adalah cerita tentang masyarakat yang terus berjuang mempertahankan identitas yang mereka banggakan sebagai orang Bali asli. Karena gringsing begitu penting dalam kehidupan masyarakat Tenganan, kain ini seperti cermin perjalanan kehidupan masyarakat setempat. Belum jelas dari mana asalnya, tetapi sampai sekarang masih ada yang mengira warna merah gringsing berasal dari darah. Mungkin kain gringsing merah yang digunakan para gadis dalam perang pandan menjadi penanda betapa beratnya pertarungan sang satria. Kepercayaan mengenai kekuatan magis kain itu lalu menghasilkan mitos sendiri. Bagaimana sebetulnya jalinan yang terjadi antara geringsing dan pertarungan dalam ritus perang pandan dalam kerangka estetika dan mitos?.

\section{Konsep Estetika}

Secara etimologis estetika berasal dari bahasa Yunani, yaitu aistheta, yang berarti hal-hal yang dapat ditanggapi dengan indra. Dalam pengertian lebih luas berarti kepekaan untuk menanggapi suatu objek, kemampuan pencerapan indra, sebagai sensivitas. Dalam bahasa Inggris menjadi aesthetics (studi tentang keindahan). Keindahan tidak semata-mata diadaptasi oleh karya seni. Keindahan bukan hak istimewa para seniman. Setiap aspek kebudayaan, setiap aspek kehidupan manusia menampilkan ciri-ciri keindahan. Sikap, tingkah laku, dan perbuatan sehari-hari menampilkan berbagai macam keindahan. Lambaian tangan, kerdip mata, dan anggukan, apabila dilakukan dengan mempertimbangkan aspek keindahan, maka akan memberikan kenikmatan pada diri sendiri dan dengan sendirinya pada orang lain. Menghargai keindahan berarti menghargai kebesaran Tuhan yang telah menciptakan keindahan ( Kutha Ratna, 2007).

Aliran estetika klasik menjelaskan hakikat keindahan senantiasa terkait dengan hal-hal ketuhanan atau teologis. Ketuhanan disini adalah objektivikasi nilai-nilai transendental yang berasal dari Tuhan atau merefleksikan nilainilai ketuhanan. Konsep aliran estetika klasik ini tidak hanya berkembang di Barat melainkan juga di Timur. Dari fenomena Tenganan misalnya, kesenian diketengahkan berdasarkan nilainilai kepercayaan, keyakinan atau ajaran-ajaran yang bersifat metafisis, transendental atau ketuhanan. Logika berpikirnya bersifat deduktif dan mutlak diakui kebenarannya. Aliran estetika ini berkembang secara tradisional dari generasi ke generasi sesuai dengan nilai kebudayaan yang berkembang dalam kehidupan kebudayaan setempat. Sebagai contoh konsep estetika Cina 
(taoisme), Jepang (zen buddhisme), Jawa (magis kosmis-mistikisme), Bali (hindu balinisme) semuanya berkembang atas dasar nilai-nilai tradisi kepercayaan budaya masyarakat yang bersangkutan (Sachari,2002).

Jika dilihat dari realitas kehidupan masyarakat Tenganan, terlihat adanya perilaku yang selalu bersinggungan dengan hal-hal yang menyangkut keindahan. Kain gringsing menjadi keharusan untuk dipakai oleh perempuan dan pemuda Tenganan, maka keindahan telah menjadi bagian gaya berpakaian. Demikian pula dengan keberadaan musik, tarian, dan peristiwa mekarekare yang menawarkan sebuah kerangka keindahan dalam sebuah upacara yang didalamnya mengandung kekuatan magis. Keindahan tersebut dengan sendirinya memberikan beragam makna di dalamnya.

Malcolm Barnard mengemukakan bermacammacam fungsi dari pakaian yang salah satunya untuk menunjukkan kondisi magis-religius. Praktik-praktik magis dan religius bergantung pada unsur-unsur seperti status resmi yang baku atau anugerah Tuhan, dan dihargai tinggi dalam tradisinya untuk menjaga tatanan. Serta menunjuk pemakaian jimat dan hiasan magis lain untuk menangkal kekuatan-kekuatan dengki spiritual dan magis (Barnard,1996: 95). Sesuai dengan mitos yang hidup dalam tatanan masyarakat Tenganan kain gringsing juga dipercaya sebagai kain yang berfungsi tolak bala bagi pemakainya.

\section{Konsep Mitos}

Mitos menjadikan pandangan dunia tertentu tampak tak terbantahkan karena alamiah atau ditakdirkan Tuhan. 'Mitos bertugas memberikan justifikasi alamiah kepada maksud-maksud historis, dan menjadikan berbagai peristiwa yang tak terduga tampak abadi' (Barthes,1972: 155). Van Peursen juga mengatakan bahwa mitos adalah sebuah cerita pemberi pedoman dan arah tertentu kepada sekelompok orang. Cerita itu berintikan lambang-lambang yang mencetuskan pengalaman manusia (van Peursen,1976: 37-42). Mitos memberi arah kepada kelakuan manusia, serta semacam pedoman bagi manusia, juga pedoman bagi manusia untuk bertindak bijaksana. Mitos menyadarkan manusia akan adanya kekuatankekuatan ajaib. Melalui mitos, manusia dibantu untuk dapat menghayati daya-daya itu sebagai suatu kekuatan yang mempengaruhi dan menguasai alam dan kehidupan sukunya. Begitu puladengan masyarakat Tenganan, mitos mengenai Dewa Indra sangat mempengaruhi sendi-sendi kehidupan mereka. Masyarakat Tenganan mempercayai bahwa perang pandan merupakan cara untuk memberikan penghormatan kepada Dewa Indra.

Mitos berdasarkan paradigma Levi-Strauss adalah kisah yang bisa dikatakan berada dalam dua waktu sekaligus, yaitu waktu yang bisa berbalik dan waktu yang tidak bisa berbalik. Pada sisi pertama mitos selalu menunjuk pada peristiwa-peristiwa yang terjadi di masa lampau. Sedangkan di sisi yang lain, pola-pola yang khas dari mitos merupakan ciri yang membuat mitos dapat relevan dan operasional dalam konteks yang ada sekarang (Shri Ahimsa, 2006; 81). Lebih jauh pola-pola tertentu yang diungkapkan mitos, bersifat timeless, tidak terikat pada waktu, atau berada pada revesible time. Hal ini menjelaskan bahwa apa yang terjadi di masa lalu, sekaligus bisa pula menjelaskan apa yang sedang terjadi sekarang, juga apa yang akan terjadi di masa mendatang.

Merujuk pada teori Levi-Strauss dan juga memahami keberadaan masyarakat Tenganan, maka kisah Dewa Indra dan Maya Denawa bagi sebagian orang Tenganan diyakini pernah terjadi di masa lampau. Kisah ini sendiri tetap bisa dipergunakan untuk memahami atau menerangkan apa yang sedang terjadi dan akan terjadi dalam masyarakat Tenganan. Bagi orang Tenganan, Dewa Indra pernah hidup di masa lampau dan sampai saat ini masih diyakini keberadaannya. Lewat mitos di atas, masyarakat diingatkan untuk melakukan ritual-ritual, memberikan penghormatan kepada kekuatankekuatan yang memberikan penjagaan dan kedamaian.

Kembali ke gringsing, kain telah menjadi representasi dari mitos yang sekian waktu dipercaya hingga kini, gringsing yang selalu memiliki makna sakral bagi warga Tenganan dipercaya mampu mengusir penyakit dan rasa sakit. Di tengah duri yang menancap di atas kulit, dengan darah segar sebagai tanda penghormatan kepada sang dewa, gringsing hadir sebagai obat yang meneguhkan hati para ksatria Tenganan. 

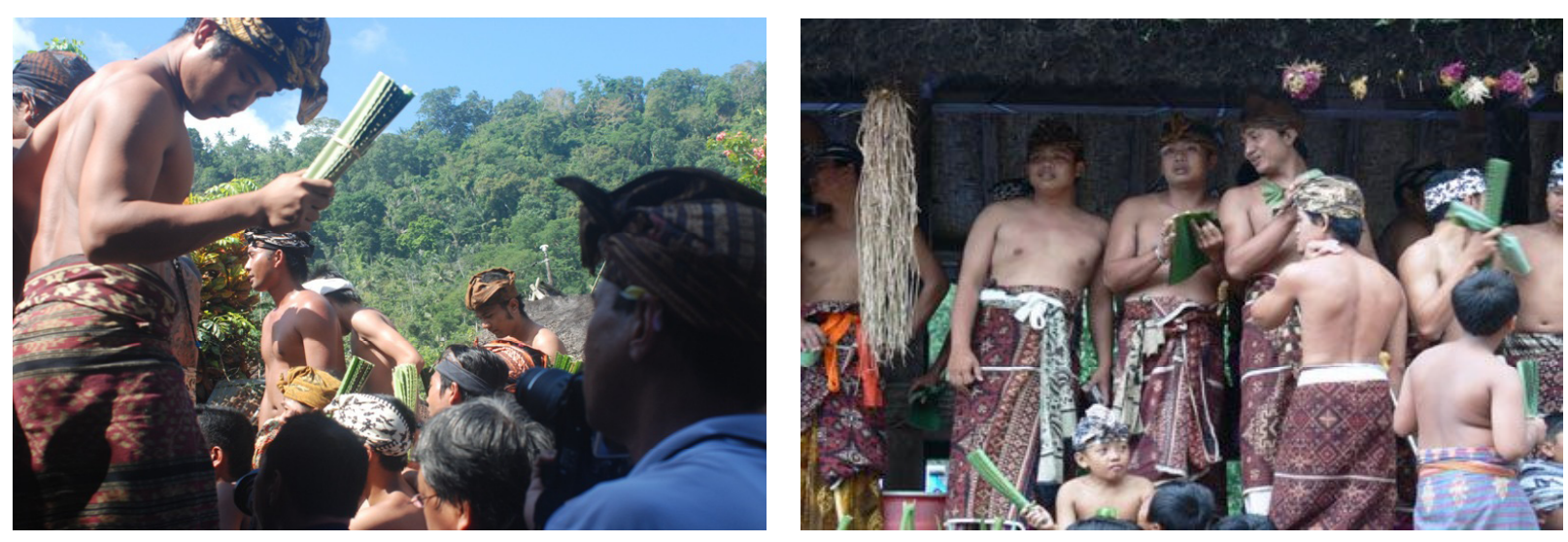

Ksatria Tenganan yang beraksi dengan berbalut gringsing (Foto: Citra, 2008)

\section{Jalinan Estetika-Mitos}

Menenun gringsing merupakan kegiatan yang dilakukan oleh masyarakat Tenganan. Hasil kerajinan menenun ini oleh masyarakat setempat dijadikan pakaian adat disamping mengandung nilai estetis, juga mengandung nilai magis yang dipercaya dapat menghilangkan penyakit.

Menurut pandangan orang Tenganan bahwa kain gringsing mengandung nilai magis. Gringsing dikenal sebagai tenun ikat ganda, yang berarti baik benang pakan maupun benang lusi diberi motif melalui teknik pengikatan. Motif gringsing yang membentuk tanda tambah menggambarkan filosofi hidup orang Tenganan, yaitu 'keseimbangan'. Sama seperti swastika, simbol keseimbangan dalam Hindu Bali (agama Siwa Buda yang dikembangkan Mpu Kuturan pada abad ke-11). Gringsing yang berasal dari kata gring berarti sakit dan sing berarti tidak, diyakini dapat mengantisipasi dan menyembuhkan penyakit. Hanya ada tiga warna yang terlihat pada gringsing, yaitu putih/kuning, merah, dan hitam yang dibuat melalui pewarnaan alam. Menurut Nyoman Sadra, secara makrokosmos putih/ kuning melambangkan oksigen atau udara yang ada di alam, merah melambangkan panas atau energi, dan hitam melambangkan air. Hal yang sama secara mikrokosmos juga ada dalam tubuh manusia. Jika ketiganya tidak seimbang, maka alam atau tubuh kita akan menjadi sakit. Oleh karena demikian orang Tenganan mempunyai pandangan bahwa kain geringsing memiliki peranan/ fungsi yang amat penting dalam kehidupannya.

Masyarakat Tenganan Pegringsingan yang menganut agama Hindu sangat percaya bahwa segala sesuatu pekerjaan yang dimulai dengan diawali upacara keagamaan maka hasilnya akan baik dan menjumpai keselamatan. Dalam memulai pekerjaan menenun gringsing yang sangat dikeramatkan inipun sangat memperhatikan aturan yang sudah diwariskan secara turun temurun oleh leluhurnya. Mereka tetap berusaha menaruh perhatian yang besar terhadap pelestarian yang sangat erat kaitannya dengan upacara keagamaan yang harus dilaksanakan demi mempertahankan keaslian tata cara pembuatan kain tenun tradisional gringsing

Pantangan bagi masyarakat Tenganan Pegringsingan untuk menenun kain gringsing pada saat datang bulan. Mengenai upacara keagamaan dilakukan secarabertahapselama proses pembuatan tenun. Rentetan adalah sebagai berikut: proses pembuatan dimulai diawali dengan mencelupkan benang kedalam minyak lilin (minyak kemiri/ malem) dan air serbuk kayu dalam wadah yang terbuat dari tanah liat kemudian ditutup kain putih hitam guna menghindari adanya pengaruh roh jahat (leak). Setelah ikatan pertama disimpulkan disertai dengan yadnya kecil yang terdiri dari : kembang sepatu, daun sirih gulung, kapur sirih, 2 set uang kepeng, pada lubangnya digantungkan benang katun yang diikat 2 kendi. Ikatan terakhir pada bahan hanya dapat diikat oleh wanita yang lewat masa menopause. Proses pembuatan kain tenun gringsing diawali dengan penyiapan kapas untuk bahan benang. Kapas yang dipakai adalah kapas keling (bijinya hanya satu satu) Mula-mula kapas keling dipipis kemudian dijadikan benang. Sesudah menjadi benang, benang itu dicelup kedalam minyak kemiri bercampur air abu/serbuk kayu dan direndam selama 42 hari. Selanjutnya benang tersebut dikeringkan tanpa menjemurnya 
di sinar matahari, diberi hiasan bunga pucuk (kembang sepatu). Kemudian benang yang sudah kering itu digulung kedalam bambu kecil yang disebut "Ulakan". Untuk motif kain pendek benang yang sudah kering diproses dengan ngelimbengang, sedang untuk motif kain panjang benang diproses dengan ngerengang. Selanjutnya benang tersebut dibedbed (diikat) untuk dapat dicelup/diwarnai, dan medbed (mengikat) sampai mendapat warna-warna yang sesuai dengan motif tenunan diperlukan waktu 2 sampai 3 minggu.

Setelah merampungkan pewarnaan benang maka benang bahan kain tenun Gringsing itu sudah siap untuk ditenun. Satu ikatan benang
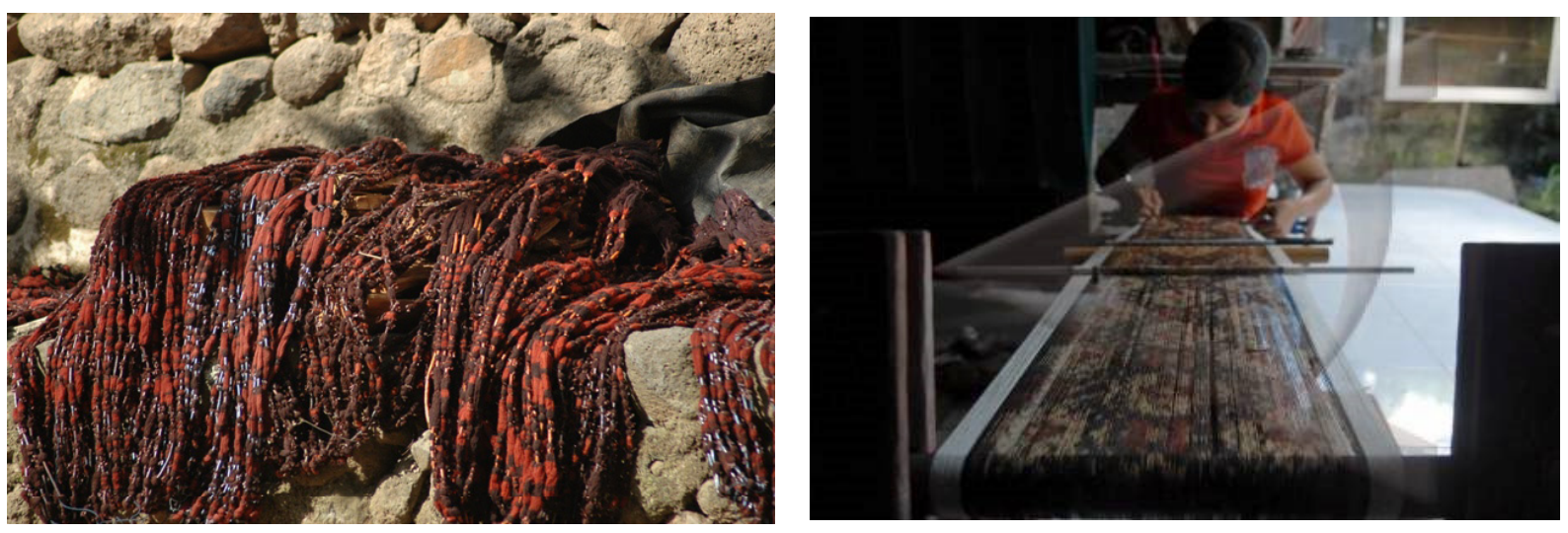

Benang gringsing yang sedang dijemur dan perempuan sedang menenun gringsing (Foto: Citra, 2009)
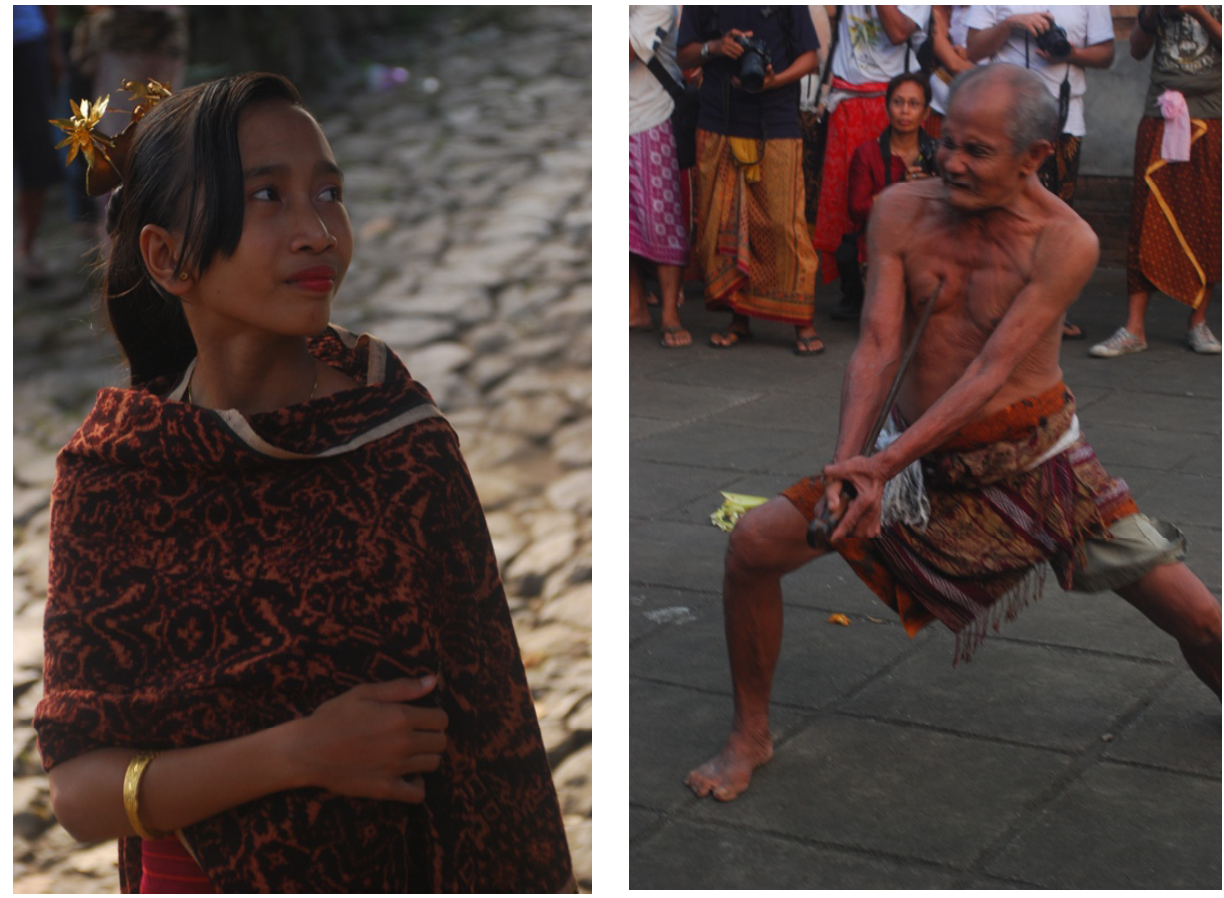

Perempuan Tenganan dengan mengenakan gringsing dan Pria Tenganan sedang ngurek dengan berbalut gringsing. (Foto: Citra, 2008) 
Malcom Barnard memberikan catatan bahwa perempuan dalam merajut atau menenun kain bukan hanya berupaya untuk sebuah pakaian. Mereka juga bisa lebih menekankah hasrat untuk membuat ornamen. Perempuan dengan demikian memiliki hasrat untuk merepresentasikan dekorasidekorasi yang indah dalam lingkungan hidupnya. Jika ini dikomparasikan dengan kreativitas tenun di Nusa Tenggara Timur, maka ada simpul yang sangat berkorelasi. Keinginan untuk membuat sesuatu yang indah hadir sebagai rasa cintanya untuk memberikan keindahan bagi kehidupan. Tidak hanya berujung pada tata cara berpakaian, tetapi keliaran untuk menyatakan keindahan bergulir seiring dengan menjaga eksistensi diri, asal klan (keluarga), dan juga keterampilan yang diturunkan. Bahkan lebih dari itu, diperlukan juga untuk sebuah status sosial.

Ukuran keindahan dalam sebuah kain secara visual bagi masyarakat Nusa Tenggara Timur dan mungkin juga di Tenganan, berawal dari keindahan mengikat berdasarkan motif. Tidak semua perempuan penenun bisa mengikat dengan tepat, baik dalam segi menentukan ornamen, akan tetapi juga bentuk ikatan. Sebuah ikatan yang kurang tepat akan mempengaruhi hasil ketika diwarnai. Begitu pula dengan jalinan yang terkesan sederhana, sebetulnya di dalamnya sangat dipengaruhi kerumitan yang sangat matematis. Hal ini bisa dibandingkan dengan kegiatan menyulam. Satu ikatan yang salah dalam menentukan hitungan maka akan terlihat nanti setelah proses perwarnaan berakhir.

Tidak semua perempuan atau penenun ahli dalam pola, biasanya hanya orang-orang tertentu yang bisa meneruskan pewarisan pola. Ini bergantung dari kemampuannya mengingat dan membaca disain. Hal lain yang sangat luar biasa adalah sebuah pola biasanya akan disimpan dan diturunkan kepada anak dan cucunya dengan janji untuk dirahasiakan. Di Ende misalnya, tidak semua klan bisa membuat pola gajah, atau tidak semua klan bisa menenun ayam. Dengan demikian sebuah pola menjadi sebuah penanda dari sebuah keluarga. Jika sebuah klan ingin membuat pola yang tidak ia kuasai, maka ia akan membayar pembuat pola ikat dari keluarga lain dengan bayaran tertentu atau perjanjian tertentu. Kerahasiaan atau penghargaan pada pola ikat tertentu terkait dengan keindahan yang hadir pada visualisasi nantinya. Keindahan pola ikat dalam hal ini bisa menjadikan penanda. Konon dahulu, ragam jenis Tenun Gringsing ada 20 jenis. Namun kini yang masih dikerjakan tinggal 7 jenis saja. Beberapa di antaranya: Gringsing Lubeng, yang terdiri dari: Gringsing Lubeng Luhur, Gringsing Lubeng Petang Dasa dan Gringsing Lubeng Pat Likur. Motifnya bernama Lubeng. Kekhasannya adalah berisi kalajengking. Lubeng Luhur ukurannya paling panjang dengan 3 bunga berbentuk kalajengking yang masih utuh bentuknya. Pada Lubeng Petang Dasa bunga kalajengkingnya utuh hanya satu di tengah sedang yang di pinggir hanya setengah-setengah, sedang Lubeng Pat Likur adalah yang ukurannya terkecil. Fungsinya sebagai busana adat dan upacara agama; Gringsing Sanan Empeg, adalah kain gringsing yang fungsinya hanya sebagai sarana upacara keagamaan dan adat, yaitu sebagai pelengkap sesajian bagi masyarakat Tenganan Pegeringsingan. Bagi masyarakat Bali di luar desa Tenganan hanya dipergunakan sebagai penutup bantal/alas kepala orang melaksanakan upacara manusa yadnya potong gigi. Ciri khas dan motif Sanan Empeg adalah adanya tiga bentuk kotak-kotak/poleng berwarna merah dan hitam; Gringsing Cecempakan adalah kain gringsing bermotif bunga cempaka. Ada beberapa jenis Gringsing Cecempakan antara lain: Gringsing Cecempakan Petang Dasa (ukuran empat puluh), Gringsing Cecempakan Putri, dan Gringsing Cecempakan Pat Likur (ukuran 24 benang). Fungsinya adalah sebagai busana adat dan upacara agama; Gringsing Cemplong adalah gringsing dengan motif bunga-bunga besar diantara bunga-bunga kecil yang seolah-olah ada kekosongan/lobang-lobang diantara bunga itu menjadi kelihatan cemplong. Adapun jenisnya : ukuran Pat Likur (24 benang), senteng/anteng (busana di pinggang wanita), sedangkan yang ukuran Petang Dasa (40 benang) sudah hampir punah. Fungsinya adalah sebagai busana adat dan upacara agama; Gringsing Isi, pada gringsing ini sesuai namanya pada motifnya semua berisi atau penuh, tidak ada bagian kain yang kosong, ukuran yang ada hanya ukuran Pat Likur (24 benang) dan berfungsi hanya untuk sarana upacara, bukan untuk busana; Gringsing Wayang, motifnya ada dua yaitu Geringsing Wayang Kebo dan Gringsing Wayang Putri. Fungsi dan ukuran kedua kain ini sama yaitu untuk selendang, yang berbeda adalah motifnya. Pada Gringsing Wayang Kebo teledunya 
(Kalajengkingnya) bergandengan sedangkan pada Gringsing Wayang Putri lepas. Pada tenun Gringsing Wayang Kebo berisi motif wayang laki dan wanita, sedangkan pada tenun Gringsing Wayang Putri hanya berisi motif Wayang Wanita; Gringsing Batun Tuung. Batun Tuung artinya biji terong. Dengan demikian pada Gringsing Batun Tuung motifnya penuh dengan biji-biji terong. Ukurannya tidak besar, untuk senteng (selendang) pada wanita dan untuk sabuk (ikat pinggang) bagi pria. Jenis Gringsing ini sudah hampir punah.

Keindahan tenun tidak hanya terletak pada ornamen atau pola ikat. Akan tetapi dari segi pewarnaan juga menjadi pertimbangan. Tidak hanya di Tenganan Pegringsingan, Kepulauan Timor juga dikenal memiliki hasil tenunan yang sangat dikenal di manca negara. Di Kepulauan Timor tidak semua penenun bisa meracik atau menciptakan warna yang indah. Mama Sii seorang penenun dari Ende misalnya menyerahkan pewarnaan kepada adiknya yang dipandang mampu meramu warna biru yang indah. Ia sendiri sangat kuat memegang pola ikat, dan juga pandai membuat warna merah dari kulit akar pohon pace. Mama Sii sangat dikenal untuk pembuatan pola ikat dan pewarnaan merah. Harmonisasi warna dan pola akan menghadirkan keindahan tertentu. Pada saat kain dicuci dan dijemur setelah proses pewarnaan berakhir, akan terlihat sebuah keindahan yang memancar karena bantuan cahaya matahari. Masyarakat yang kebetulan melewatinya akan memberikan komentar jika keindahan itu ia dapatkan secara visual. Gagah adalah sebuah komentar atas keindahan sebuah tenun yang mereka sendiri yang mengerti ukurannya. Sangat spesifik, primordial, dan menjadi kesepakatan bersama sebuah masyarakat. Ada di dalamnya nilai yang sulit diungkapkan. Keindahan tenun dari mama Sii terkait dengan pola yang memang sangat sulit dikuasai oleh klan lain. Apalagi pola tersebut juga sangat dilarang untuk disebarluaskan. Ini menjadi ciri khas dan penanda sebuah keluarga. Pola ikat seakan sebuah disain yang bernuansakan "mitis" karena memiliki sejarah dan dijaga sebagai sesuatu yang "berharga". Secara metafisis ternyata ini juga sangat mempengaruhi harga sebuah kain tenun di Flores. Kain hasil tenunan mama Sii dengan pewarnaan alami paling rendah berkisar $1,5-5$ juta rupiah perpotong dalam bentuk sarung. Akan tetapi ukuran ini menjadi sangat relatif karena sebetulnya mereka tak biasa untuk menjual kain-kain yang dimiliki keluarga. Mereka membuat tenun indah untuk dipakai upacara, disimpan, dan untuk kebutuhan "belis" atau mas kawin. Beberapa tenun dari keluarga perempuan akan ditukar kerbau, kuda, babi, ayam dan perhiasan. Bisa dibayangkan dalam hal ini nilai selembar tenun dalam adat di Flores.
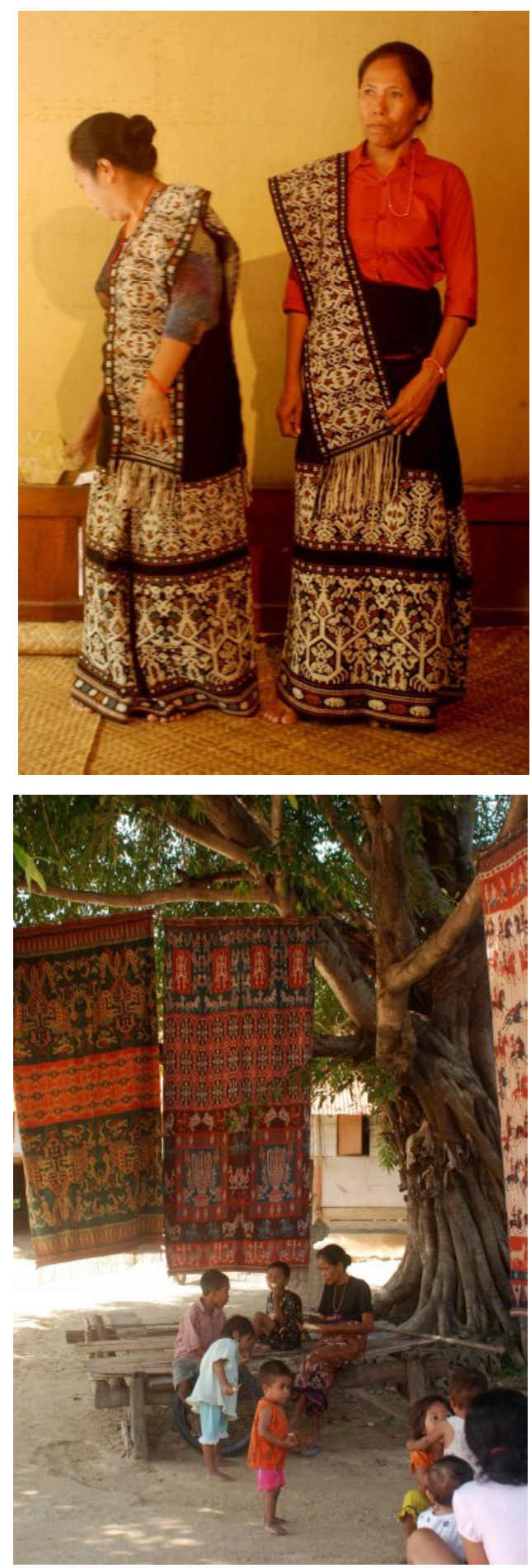

Keindahan tenun Flores (Foto: Made, 2007) 


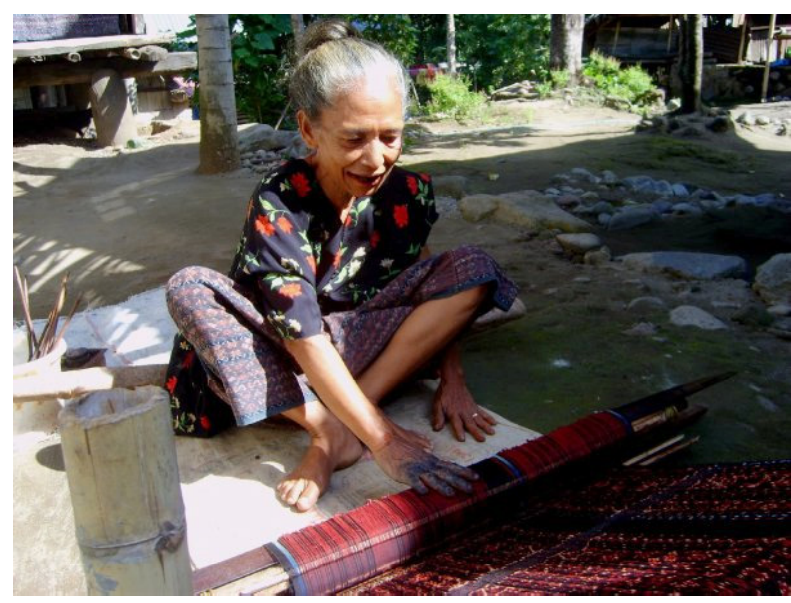

'Mama Sii' dari Ende Flores sedang menenun (Foto: Made, 2007)

Keindahan dalam hal ini adalah suatu jalinan yang tak bisa dipisahkan antara pola ikat, pewarnaan, dan nilai-nilai intrisik dari sebuah kebudayaan suatu bangsa. Ada makna-makna tertentu yang terdapat pada sebuah kain. Tenun Flores memiliki kesetaraan atau korelasi makna yang bersesuaian dengan di Tenganan. Orang Tenganan Pegringsingan saat ini bukan termasuk 'pecinta' lingkungan, tetapi mereka adalah orang-orang yang sangat taat pada tradisi dan leluhurnya. Salah satunya dengan cara tidak melanggar awig-awig desa yang telah dibuat para leluhur sejak ratusan tahun yang lalu. Kondisi inilah yang menjadi salah satu penyebab hutan Tenganan Pegringsingan masih 'lestari' sejak ratusan tahun yang lalu. Ketika akan membuat gringsing yang dapat mendatangkan keuntungan besar, mereka tidak dapat membuat dalam jumlah banyak. Mereka harus menunggu buah kemiri jatuh sendiri dari pohon. Buah kemiri memang dapat dibeli di tempat lain, tetapi warna yang dihasilkan tidak sebaik warna kemiri dari hutan Tenganan Pegringsingan. Sebaliknya, mereka tidak akan menebang pohon kemiri. Demikian halnya dengan pohon mengkudu dan kepundung. Kedua jenis pohon itu harus tetap ada di Tenganan Pegringsingan. Secara tidak langsung orang Tenganan Pegringsingan telah melakukan konservasi di dalam wilayahnya. Konservasi tidak hanya dilakukan di dalam wilayah mereka, melainkan juga di desa tetangga. Proses pemberian warna biru tidak boleh dilakukan di dalam desa. Secara tidak langsung leluhur orang Tenganan Pegringsingan mengajak orang-orang yang tinggal di sekitarnya juga melakukan konservasi.
Bukan hanya pohon nila yang harus tetap ada di sekitar desa, termasuk juga pohon sirih, beras ketan, dan pisang kayu. Sedikitnya tujuh jenis pohon 'terselamatkan' oleh keberadaan gringsing. Belum termasuk pohon kapas sebagai bahan dasar benang geringsing. Sampai saat ini benang tersebut mereka beli dari Nusa Penida. Kerja sama antardesa sudah dilakukan sejak dulu melalui gringsing. Walaupun mereka yang hidup saat ini tidak 'mempedulikan' lingkungannya, tetapi leluhur mereka adalah orang-orang yang sangat peduli terhadap lingkungan dengan membuatnya tetap lestari. Kepedulian diungkapkan lewat tradisi dan awig-awig yang dibuat. Kepedulian ini pada dasarnya bertujuan untuk menjaga keseimbangan alam. Jika alam dalam posisi seimbang, maka kehidupan akan terus berlanjut. Filosofi ini dapat dilihat melalui motif kain gringsing. Setiap kain selalu mengandung unsur 'tanda tambah' yang melambangkan keseimbangan. Selain itu, motif yang ada selalu menggambarkan unsurunsur alam, seperti bunga cempaka, kerbau, atau tapak kaki ayam. Sampai saat ini orang Tenganan Pegringsingan masih memegang prinsip bahwa mereka merupakan bagian dari alam. Meskipun mereka tidak memahami makna atau tujuan setiap upacara dan awig-awig yang ada, tetapi secara prinsip mereka sadar bahwa segala sesuatu yang dilakukan mempunyai tujuan akhir untuk keberlanjutan hidup. Hidup dapat terus berlangsung jika semua unsur yang ada di alam, terutama udara, panas, dan air dalam posisi seimbang. Ketika orang luar ingin melihat 'kebudayaan' Tenganan Pegringsingan, hal itu dapat dilihat dalam hidup keseharian masyarakatnya. Karena kebudayaan merupakan sebuah proses, bukan barang antik yang harus dimuseumkan. Orang Tenganan Pegringsingan tidak ingin dijadikan objek pariwisata sebagai 'barang antik' yang dicap tradisional. Bagi mereka, tradisional atau modern bukan merupakan satu hal yang harus dipermasalahkan. Namun yang terpenting adalah keseimbangan.

\section{Penutup}

Kehadiran gringsing tak bisa dilihat hanya pada sebuah lembaran kain tetapi kebudayaan atau tatanan sebuah masyarakat. Gringsing akan memaknai kehadiran manusia dalam merangkai keindahan, dan tradisi atau tata aturan sebuah 
masyarakat yang terkait dengan ritual. Melebihi desa lainnya di Bali, masyarakat Tenganan melakukan ritual keagamaan setiap hari untuk menjaga kemurnian rohani serta keseimbangan sosial desa. Adapun kegiatan yang paling terkenal dan menjadi pusat perhatian dalam bulan kelima adalah perang pandan. Budaya Tenganan sangat unik, semua mengacu pada konsep keseimbangan. Filosofi ini ditandai dengan motif di atas kain gringsing, tenun ikat ganda yang menggunakan pewarna alam dengan proses pembuatan yang sangat sulit dan lama. Unsur keseimbangan dalam hidup agar manusia menjaga tiga elemen, yaitu api, air, dan udara yang diidentikkan dengan warna-warna tertentu dalam kain khas Tenganan Pegeringsingan. Orang Tenganan mempunyai aturan tentang cara mengelola lingkungannya, termasuk hutan bercampur kebun yang mengelilingi desa, sehingga sampai saat ini hutan Tenganan tetap terjaga dengan baik untuk keseimbangan dan keberlanjutannya. Dewa Indra yang selalu dipuja oleh masyarakat Tenganan dihormati dengan sebuah ritus perang, rasa sakit seolah sirna oleh gringsing yang selalu membalut diri. Semua telah tertata dalam aturan keseimbangan dalam awig-awig. Jalinan serasi antara mitos dan estetika, semua direpresentasikan dengan begitu indahnya di Tenganan.

\section{Kepustakaan}

Barnard, Malcolm. 1996. Fashion Sebagai Komunikasi. Terj. Idy Subandy Ibrahim. Yogyakarta: Jalasutera.

Barthes, Roland. 1972. Mythologies. London: Cape.

Heddy Shri Ahimsa-Putra. 2006. Strukturalisme Levi-Strauss Mitos dan Karya Sastra. Yogyakarta: Kepel Press.

Kutha Ratna, Nyoman. 2007. Estetika Sastra dan Budaya. Yogyakarta: Pustaka Pelajar.

Peursen, Van. 1976. Strategi Kebudayaan. Yogyakarta: Kanisius.

Sachari. 2002. Estetika Makna Simbol dan Daya. Bandung: ITB.

\section{Informan}

Nyoman Sadra (62 tahun), Seniman 